\title{
KARAKTERISTIK MINUMAN JELI IKAN LELE (Clarias sp.) YANG DIPENGARUHI OLEH PEMANIS DAN KARAGENAN
}

\author{
Willy Pranata Widjaja \\ Sumartini \\ K.N. Salim \\ Program Studi Teknologi Pangan, Fakultas Teknik, Universitas Pasundan \\ Jl. Dr. Setiabudhi No. 9,Bandung, 40153, Indonesia \\ E-mail : willy_tp@unpas.ac.id
}

\begin{abstract}
Abstrak
Telah dilakukan penelitian megenai karakteristik minuman jeli ikan lele yang dipengaruhi oleh konsentrasi pemanis buatan dan karagenan. Penelitian ini diharapkan dapat memberikan informasi mengenai produk diversifikasi ikan lele menjadi produk yang mempunyai nilai ekonomis dan memiliki nilai gizi yang tinggi. Penelitian dilakukan dalam dua tahap. Tahap pertama dilakukan untuk mengetahui jenis pemanis buatan yang sesuai untuk minuman jeli ikan lele. Penentuan berdasarkan uji skala hedonik dengan parameter warna, aroma, dan rasa. Sedangkan tahap kedua dilakukan untuk menentukan konsentrasi jenis pemanis buatan terpilih (sakarin:siklamat) dengan konsentrasi 0.02\%:0.06\% b/b; $0.014 \%: 0.042 \% \mathrm{~b} / \mathrm{b} ; 0.01 \%: 0.03 \% \mathrm{~b} / \mathrm{b}$ dan konsentrasi karagenan $0.1 \% ; 0.2 \% ; 0.3 \% \mathrm{~b} / \mathrm{b}$. Pada penelitian ini digunakan Rancangan Acak Kelompok (RAK) dengan pola faktorial 3x3 tiga kali pengulangan yang dilanjutkan uji Duncan. Pengujian meliputi respon kimia yaitu analisis uji kadar gula pereduksi (metoda titrimetri), respon fisik meliputi uji $\mathrm{pH}$ menggunakan $\mathrm{pH}$ meter, uji total padatan terlarut (metoda gravimetric), dan viskositas menggunakan viskometer. Hasil penelitian menunjukkan bahwa konsentrasi pemanis buatan berpengaruh nyata terhadap karakteristik minuman jeli ikan lele, yaitu terhadap respon viskositas, total padatan terlarut, rasa, dan tekstur. Tetapi tidak berpengaruh nyata terhadap respon kadar gula reduksi, $\mathrm{pH}$, warna, dan aroma. Konsentrasi karagenan berpengaruh nyata terhadap karakteristik minuman jeli ikan lele, yaitu respon viskositas, total padatan terlarut, $\mathrm{pH}$, rasa, dan tekstur. Tetapi tidak berpengaruh nyata terhadap respon kadar gula reduksi, warna, dan aroma. Interaksi konsentrasi pemanis buatan, dan konsentrasi karagenan berpengaruh nyata terhadap karakteristik minuman jeli ikan lele, yaitu respon viskositas, total padatan terlarut, $\mathrm{pH}$, rasa, dan tekstur. Namun, tidak berpengaruh nyata terhadap respon kadar gula reduksi, warna, dan aroma. Sampel terpilih adalah formula a3b3, yaitu dengan penambahan pemanis buatan (sakarin : siklamat) sebanyak $0.1 \%$ : 0,03\%, dan karagenan sebanyak 0,3\% dengan $\mathrm{pH} 5,50$, kadar gula pereduksi 7,17\%, viskositas $866,67 \mathrm{mPas}$, total padatan terlarut $20,54{ }^{\circ}$ Brix, dan kadar protein $3.80 \%$.
\end{abstract}

Kata kunci : minuman jeli, ikan lele, pemanis buatan, karagenan.

\section{Pendahuluan}

Minuman jeli merupakan salah satu alternatif panganan ringan yang banyak disukai oleh anak-anak, remaja bahkan dewasa. Minuman jeli atau jelly drink dapat menjadi minuman fungsional yang berfungsi sebagai pelepas dahaga dan membantu mengatasi rasa lapar karena kandungan dietary fibre-nya (Hapsari, 2011) serta mempunyai potensi pasar yang besar untuk dikembangkan karena saat ini di kota-kota besar terjadi perpindahan pola konsumsi pangan yang cenderung ke arah pola konsumsi instan atau cepat saji dan praktis salah satunya yaitu minuman jeli (Saputra, 2007).

Minuman jeli merupakan minuman ringan berbentuk gel yang dibuat dari pektin, agar-agar, karagenan, gelatin atau senyawa hidrokoloid lainnya dengan penambahan gula, asam, dan atau tanpa bahan tambahan makanan lain yang diizinkan (Yulianti,2008). Produk minuman jeli diharapkan menjadi alternatif minuman sari buah yang dapat mengatasi kestabilan pada sari buah karena minuman ini memiliki konsistensi gel sehingga dapat menghindari pengendapan, namun mudah diminum. Minuman jeli memiliki konsistensi gel yang lemah sehingga memudahkan untuk disedot sebagai minuman. Syarat minuman jeli yang baik, yaitu transparan, mempunyai aroma serta rasa buah yang asli. Tekstur yang diinginkan adalah saat dikonsumsi menggunakan sedotan mudah hancur, namun bentuk gel masih terasa di mulut (Limanto, 2011).

Minuman jeli yang saat ini beredar di pasaran umumnya dibuat dari air dan sari buah-buahan atau sayuran serta hanya mengedepankan kandungan serat pangan dan vitamin C. Pada penelitian ini dibuat produk diversifikasi minuman jeli, yaitu minuman jeli ikan lele. Ikan lele dipilih karena merupakan salah satu ikan yang mengandung protein, asam amino esensial dan sejumlah asam lemak esensial omega3,6 dan 9 
yang memiliki fungsi fisiologis bagi tubuh yang bermanfaat bagi anak-anak maupun dewasa, harganya relatif murah serta jumlah produksinya cukup tinggi. Produksi ikan lele di Indonesia dari tahun 2009 sampai triwulan ketiga tahun 2014 mengalami peningkatan sebesar $37.49 \%$ dengan jumlah produksi pada tahun 2014 sebanyak 463.221 ton (Direktorat Jendral Perikanan Budidaya, 2013).

Keunggulan ikan lele dibandingkan dengan produk hewani lainnya adalah kaya akan Leusin dan Lisin. Leusin $\left(\mathrm{C}_{6} \mathrm{H}_{13} \mathrm{NO}_{2}\right)$ merupakan asam amino esensial yang sangat diperlukan untuk pertumbuhan anak-anak dan menjaga keseimbangan nitrogen. Leusin juga berguna untuk perombakan dan pembentukan protein otot. Lisin merupakan salah satu dari 9 asam amino esensial yang dibutuhkan untuk pertumbuhan dan perbaikan jaringan. Lisin termasuk asam amino yang sangat penting dan dibutuhkan sekali dalam pertumbuhan dan perkembangan anak (Suryaningrum, 2012). Lele juga merupakan sumber asam lemak omega 3, yaitu asam lemak dengan ikatan rangkap pada posisi karbon nomor 3 dari gugus metil atau disebut karbon posisi omega. Asam lemak ini merupakan precursor dari thrombaxiane A3 dan prostaglandin I3, zat yang sangat efektif untuk pengganti agregasi keping-keping darah. Pencegahan agregasi keping-keping darah dapat mengurangi risiko menderita penyakit jantung (Willy, 2009 dan Suryaningrum, 2012).

Minuman jeli harus memiliki tekstur kokoh, saat dikonsumsi menggunakan bantuan sedotan mudah hancur, namun bentuk gelnya masih terasa dimulut (Pranajaya, 2007), begitu pula pada minuman jeli ikan lele.

Menurut Peraturan Menteri Kesehatan nomor 033 tahun 2012 tentang bahan tambahan pangan, pemanis (sweetener) adalah bahan tambahan pangan berupa pemanis alami dan pemanis buatan yang memberikan rasa manis pada produk. Pemanis buatan (artifical sweetener) adalah pemanis yang diproses secara kimiawi, dan senyawa tersebut tidak terdapat di alam, pemanis buatan terdiri atas asesulfam-k, aspartam, siklamat, sakarin, sukralosa, dan neotam.

Penggunaan pemanis buatan pada penelitian ini bertujuan untuk menggantikan fungsi gula sebagai pemberi rasa manis, juga sebagai penegas cita rasa (flavour enhancer) terutama cita rasa buah serta untuk mengurangi kadar kalori pada produk pangan. Pemanis buatan umumnya digunakan oleh individu dengan kondisi kesehatan tertentu yang membatasi asupan gula, misalnya pada penderita diabetes untuk mengatasi kenaikan kadar gula dalam darah atau pada penderita obesitas untuk mengurangi kadar kalori dalam diet. Penggunaan pemanis buatan semakin meluas, tidak hanya dimanfaatkan oleh penderita diabetes dan obesitas, namun juga oleh konsumen yang sedang menjalani diet rendah kalori untuk mengendalikan 2 asupan kalorinya. Produk pangan yang mengandung pemanis buatan biasanya diberi label "sugar-free" atau "diet", misalnya pada produk minuman ringan, minuman serbuk, susu, makanan ringan, atau permen. Namun demikian, tidak semua produk pangan yang beredar di pasaran mencantumkan label "sugar-free" atau "diet" pada kemasannya, oleh karena itu disarankan konsumen tetap harus membaca komposisi pada label untuk mengetahui ada tidaknya kandungan pemanis buatan dalam suatu produk pangan (POM, 2014).

Oleh karena itu perlu dilakukan penelitian untuk mengetahui jenis pemanis buatan yang sesuai untuk minuman jeli ikan lele serta untuk menentukan pengaruh konsentrasi karagenan dalam pembutan minuman jeli ikan lele yang memiliki nilai gizi dan dapat diterima masyarakat.

\section{Bahan, Alat dan Metode Penelitian}

\section{Bahan-bahan Penelitian}

Bahan baku utama yang digunakan dalam penelitian ini adalah ikan lele sangkuriang (Clarias sp.) segar yang diperoleh dari tempat Penangkaran Ikan Lele Ciwastra Bandung, berumur 2.5-3 bulan dan memiliki berat $1.5-2.0$ ons (5-6 ekor/kg), karagenan yang diperoleh dari Toko Sejati Bandung, asesulfam-k, siklamat, dan sakarin yang diperoleh dari Toko Seger Bandung, jeruk lemon dan air mineral yang diperoleh dari supermarket. Bahan-bahan yang digunakan untuk analisis yaitu bahan kimia dan reagen analisis gula pereduksi dengan metode Luff Schrool, bahan kimia dan reagen analisis protein dengan metode Kjeldahl.

\section{Alat-alat Penelitian}

Alat-alat penelitian yang digunakan untuk analisis antara lain yaitu neraca analitik, kertas timbang, oven, cawan alumunium, penjepit cawan, desikator, pipet volumetric, seperangkat alat analisis Kjeldahl, seperangkat alat analisis volumetri, refraktometer, dan $\mathrm{pH}$ meter.

\section{Metodologi Penelitian}

\section{Preparasi sampel}

Sampel ikan lele (Clarias sp.) dari penangkaran ikan dibawa dalam keadaan hidup menggunakan plastik besar berisi air kolam dan diberikan oksigen ke laboratorium penelitian untuk segera dimatikan dan dipersiapkan untuk tahap pengolahan berikutnya.

Penelitian yang akan dilakukan meliputi 2 tahap. Tahap pertama dilakukan untuk mengetahui jenis pemanis buatan yang sesuai untuk minuman jeli ikan lele berdasarkan tingkat kesukaan terhadap parameter warna, aroma, dan rasa. Sedangkan tahap kedua dilakukan untuk menentukan konsentrasi jenis pemanis buatan terpilih (sakarin:siklamat) dengan konsentrasi $0.02 \%: 0.06 \% \mathrm{~b} / \mathrm{b} ; \quad 0.014 \%: 0.042 \%$ 
$\mathrm{b} / \mathrm{b} ; 0.01 \%: 0.03 \% \mathrm{~b} / \mathrm{b}$ dan konsentrasi karagenan $0.1 \% ; 0.2 \% ; 0.3 \% \mathrm{~b} / \mathrm{b}$. Pada penelitian ini digunakan Rancangan Acak Kelompok (RAK) dengan pola faktorial 3x3 tiga kali pengulangan yang dilanjutkan uji Duncan. Pengujian meliputi respon kimia yaitu analisis uji kadar gula pereduksi (metoda titrimetri), respon fisik meliputi uji $\mathrm{pH}$ menggunakan $\mathrm{pH}$ meter, uji total padatan terlarut (metoda gravimetric), dan viskositas menggunakan viskometer.

Pembuatan minuman jeli ikan lele seperti ditunjukkan pada Gambar 1.

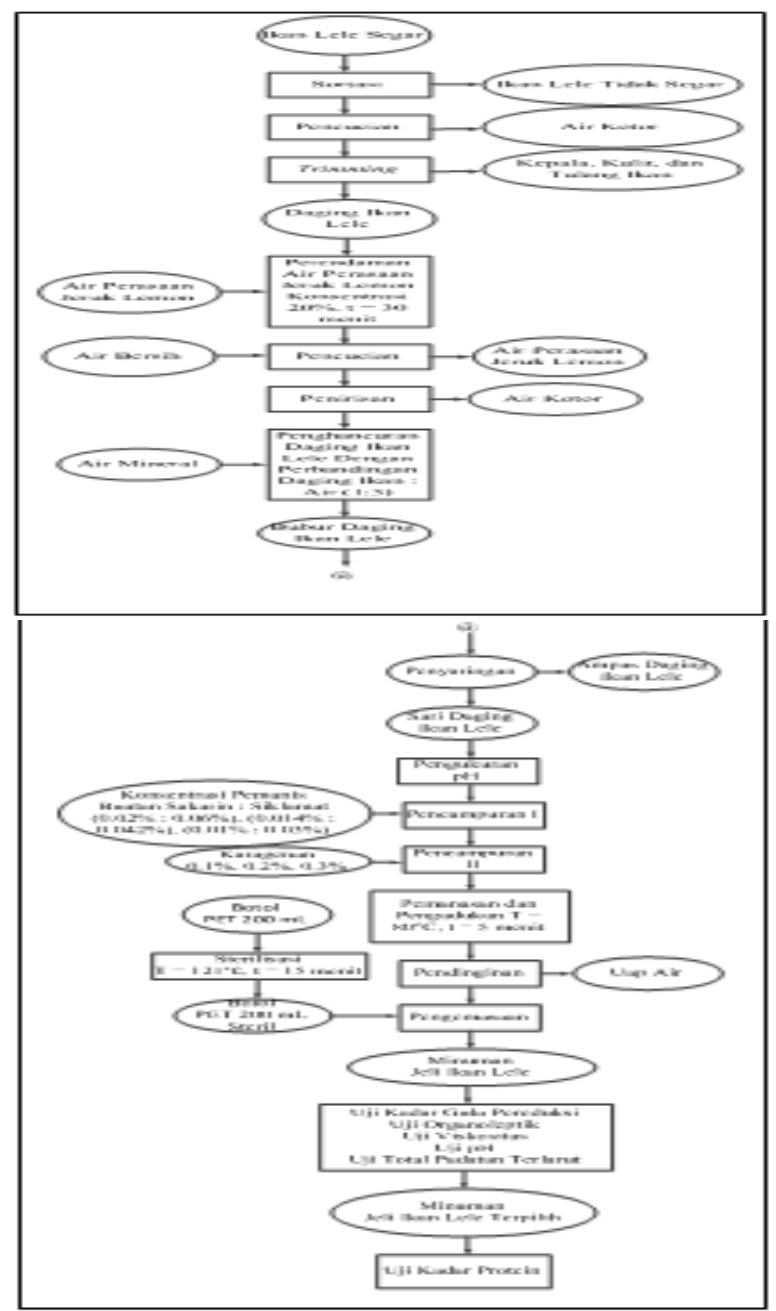

Gambar 1. Diagram Alir Pembuatan Minuman Jeli Ikan Lele

\section{Hasil dan pembahasan}

\section{Penelitian Tahap Pertama}

Penelitian tahap pertama dilakukan untuk menentukan jenis pemanis buatan yang akan digunakan pada penelitian tahap kedua berdasarkan tingkat penerimaan panelis terhadap warna, aroma dan rasa.

\section{Warna}

Berdasarkan perhitungan analisis variansi terhadap nilai kesukaan warna minuman jeli ikan lele menunjukkan bahwa perlakuan pengaruh jenis pemanis buatan, tidak berpengaruh terhadap warna minuman jeli ikan lele, seperti ditunjukkan pada Tabel 1.

Tabel 1. Pengaruh Jenis Pemanis Buatan Terhadap Nilai Rerata Kesukaan Warna Minuman Jeli Ikan Lele

\begin{tabular}{|c|c|}
\hline Jenis Pemanis Buatan (A) & $\begin{array}{c}\text { Rerata Nilai Kesukaan } \\
\text { Warna }\end{array}$ \\
\hline 111 (Asesulfam-k) & $2,02^{\mathrm{a}}$ \\
\hline 110 (Sakarin : Siklamat) & $2,14^{\mathrm{a}}$ \\
\hline
\end{tabular}

Keterangan : Setiap huruf yang berbeda menunjukkan adanya perbedaan yang nyata pada taraf 5\% Uji Duncan.

Data menunjukkan bahwa tidak ada efek perubahan warna pada masing-masing minuman jeli ikan lele. Pemanis buatan memiliki tingkat kelarutan yang tinggi sehingga akan mudah larut didalam air. Pada proses pelarutan pemanis terjadi pemisahan molekul-molekul gula dari permukaan kristal gula menuju ke dalam air yang akan menghasilkan warna bening (Yanto,2015).

\section{Aroma}

Berdasarkan hasil uji hedonik terhadap aroma minuman jeli ikan lele dengan dua jenis pemanis buatan yang berbeda (Asesulfam-K dan Sakarin : Siklamat), dapat dilihat data hasil perhitungan menunjukkan bahwa pada kedua sampel minuman jeli ikan lele tidak berpengaruh terhadap respon aroma. Oleh karena itu tidak perlu dilakukan Uji Lanjut Duncan. Hal ini dapat diketahui bahwa semakin kental minuman jelly, penerimaan terhadap intesitas rasa, bau, dan cita rasa lainnya semakin berkurang (Winarno, 1992).

\section{Rasa}

Berdasarkan perhitungan analisis variansi terhadap nilai kesukaan rasa minuman jeli ikan lele menunjukkan bahwa perlakuan pengaruh jenis pemanis buatan, berpengaruh terhadap rasa minuman jeli ikan lele. Hal ini dapat dilihat pada Tabel 6.

Tabel 2. Pengaruh Jenis Pemanis Buatan Terhadap Nilai Rerata Kesukaan Rasa Minuman Jeli Ikan Lele

\begin{tabular}{|c|c|}
\hline Jenis Pemanis Buatan (A) & $\begin{array}{c}\text { Rerata Nilai Kesukaan } \\
\text { Rasa }\end{array}$ \\
\hline 111 (Asesulfam-k) & $1,75^{\mathrm{a}}$ \\
\hline 110 (Sakarin : Siklamat) & $1,97^{\mathrm{b}}$ \\
\hline
\end{tabular}

Keterangan : Setiap huruf yang berbeda menunjukkan adanya perbedaan yang nyata pada taraf $5 \%$ Uji Duncan.

Hasil analisis menunjukkan bahwa jenis pemanis buatan kode sampel 111 (Asesulfam-K) berbeda nyata dengan jenis pemanis buatan kode sampel 110 (Sakarin : Siklamat) dalam hal rasa minuman jeli ikan lele. Respon kesukaan panelis untuk 
sampel 110 (Sakarin : Siklamat) memiliki nilai yang tinggi terhadap rasa minuman jeli ikan lele dibandingkan terhadap sampel dengan kode 111 (Asesulfam-K), karena sakarin memiliki rasa manis sebesar 300 kali lebih manis daripada gula, dan siklamat memiliki rasa manis sebesar 30-50 kali lebih manis daripada gula, sedangkan asesulfam-k memiliki rasa 200 kali lebih manis daripada gula (Cahyadi, 2008).

Penggunaan sakarin biasanya dicampurkan dengan bahan pemanis lain seperti siklamat atau aspartame. Hal itu dimaksudkan untuk menutupi rasa tidak enak dari sakarin dan memperkuat rasa manis. Menurut Cahyadi (2008), kombinasi sakarin dan sikalamat dengan perbandingan 1:3 merupakan campuran paling baik sebagai pemanis yang menyerupai gula dalam minuman. Oleh karena itu pada minuman jeli ikan lele kode sampel 110 (Sakarin : Siklamat) sakarin dicampurkan dengan siklamat, bertujuan untuk menutupi rasa tidak enak dari sakarin dan memperkuat rasa manis pada minuman jeli ikan lele, sehingga kode sampel 110 (Sakarin : Siklamat) memiliki rasa manis yang disukai oleh panelis lebih tinggi dibandingkan dengan kode sampel 111 (Asesulfam-K).

\section{Penelitian Tahap Kedua}

Penelitian tahap ini merupakan kelanjutan dari penelitian tahap pertama. Tujuan dilakukan penelitian ini untuk menentukan konsentrasi jenis pemanis buatan sakarin-siklamat dan untuk menentukan konsentrasi karagenan terhadap karakteristik minuman jeli ikan lele.

\section{Gula Pereduksi}

Berdasarkan data hasil perhitungan anava, konsentrasi karagenan dan interaksi konsentrasi pemanis buatan, konsentrasi karagenan, dan konsentrasi pemanis buatan tidak berpengaruh nyata terhadap respon kadar gula pereduksi.

Menurut Winarno (2007), proses inversi sukrosa terjadi pada suasana asam, dimana semakin tinggi suhu pemanasan maka semakin banyak presentase gula invert yang terbentuk. Sari daging ikan lele cenderung bersifat asam dan karagenan cenderung bersifat basa, sehingga semakin tinggi konsentrasi karagenan maka semakin basa $\mathrm{pH}$ minuman jeli ikan lele. Oleh karena itu konsentrasi karagenan tidak berpengaruh nyata terhadap kadar gula pereduksi minuman jeli ikan lele.

\section{Viskositas}

Berdasarkan perhitungan anava, menunjukan bahwa konsentrasi karagenan, konsentrasi pemanis buatan, dan interaksi konsentrasi pemanis buatan dan konsentrasi karagenan berpengaruh nyata terhadap respon uji viskositas yang diuji dengan menggunakan alat viskometer. Pengaruh pemanis buatan terhadap viskositas ditampilkan pada Tabel 3.

Tabel 3. Pengaruh Konsentrasi Pemanis Buatan Terhadap Viskositas Minuman Jeli Ikan Lele

\begin{tabular}{|c|c|}
\hline $\begin{array}{c}\text { Konsentrasi Pemanis } \\
\text { Buatan }\end{array}$ & $\begin{array}{c}\text { Rerata Nilai Viskositas } \\
(\mathrm{mPa} . \mathrm{s})\end{array}$ \\
\hline $\mathrm{a} 1(0.02 \%: 0.06 \%)$ & $397,22^{\mathrm{a}}$ \\
\hline $\mathrm{a} 2(0.014 \%: 0.042 \%)$ & $622,22^{\mathrm{b}}$ \\
\hline $\mathrm{a} 3(0.01 \%: 0.03 \%)$ & $1241,67^{\mathrm{c}}$ \\
\hline
\end{tabular}

Keterangan : Setiap huruf yang berbeda menunjukkan adanya perbedaan yang nyata pada taraf $5 \%$ Uji Duncan.

Berdasarkan Tabel 3, data menunjukkan bahwa semakin bertambahnya konsentrasi pemanis buatan, maka viskositas minuman jeli ikan lele semakin meningkat. Hal ini, disebabkan karena gula mempunyai sifat hidrofilik yang disebabkan oleh adanya gugus hidroksil dalam struktur molekulnya. Gugus hidroksil tersebut akan berikatan dengan molekul air melalui ikatan hydrogen, akibat keadaan tersebut air yang terdapat di dalam bahan pangan akan berkurang, sehingga minuman jelly ikan lele semakin kental (Winarno, 1997).

Tabel 4. Pengaruh Konsentrasi Karagenan Terhadap Viskositas Minuman Jeli Ikan Lele

\begin{tabular}{|c|c|}
\hline Konsentrasi Karagenan & $\begin{array}{c}\text { Rerata Nilai Viskositas } \\
(\mathrm{mPa} . \mathrm{s})\end{array}$ \\
\hline b1 $(0.1 \%)$ & $572,22^{\mathrm{a}}$ \\
\hline b2 $(0.2 \%)$ & $613,89 \mathrm{~b}$ \\
\hline b3 $(0.3 \%)$ & $661,11^{\mathrm{c}}$ \\
\hline
\end{tabular}

Keterangan : Setiap huruf yang berbeda menunjukkan adanya perbedaan yang nyata pada taraf 5\% Uji Duncan.

Data pada Tabel 4 menunjukkan bahwa semakin bertambahnya konsentrasi karagenan, maka viskositas minuman jeli ikan lele semakin meningkat. Hal ini, disebabkan karena karagenan akan mengikat air dalam jumlah besar, karena semakin banyak air yang terikat dan terperangkap sehingga larutan bersifat lebih kental. karagenan akan mengikat air dalam jumlah besar yang menyebabkan ruang antar partikel menjadi lebih sempit sehingga semakin banyak air yang terikat dan terperangkap menjadikan larutan bersifat keras (Wicaksono, dkk, 2015).

Pengaruh interaksi konsentrasi pemanis buatan dan konsentrasi karagenan ditampilkan pada Tabel 5. 
Tabel 5. Dwi Arah Terhadap Viskositas Minuman Jeli Ikan Lele

\begin{tabular}{|c|c|c|c|}
\hline \multirow{2}{*}{ Pemanis Buatan } & \multicolumn{3}{|c|}{ Karagenan } \\
\cline { 2 - 4 } & $\mathrm{b} 1$ & $\mathrm{~b} 2$ & $\mathrm{~b} 3$ \\
& $(0.1 \%)$ & $(0.2 \%)$ & $(0.3 \%)$ \\
\hline \multirow{3}{*}{ a1 $(0.02 \%: 0.06 \%)$} & $\mathrm{A}$ & $\mathrm{A}$ & $\mathrm{A}$ \\
& 350,00 & 400,00 & 441,67 \\
& $\mathrm{a}$ & $\mathrm{B}$ & $\mathrm{c}$ \\
\hline \multirow{2}{*}{$\mathrm{a} 2(0.014 \%:$} & $\mathrm{B}$ & $\mathrm{B}$ & $\mathrm{B}$ \\
$0.042 \%)$ & 575,00 & 616,67 & 675,00 \\
& $\mathrm{a}$ & $\mathrm{b}$ & $\mathrm{c}$ \\
\hline & $\mathrm{C}$ & $\mathrm{C}$ & $\mathrm{C}$ \\
$\mathrm{a} 3(0.01 \%: 0.03 \%)$ & 791,67 & 833,33 & 866,67 \\
& $\mathrm{a}$ & $\mathrm{B}$ & $\mathrm{c}$ \\
\hline
\end{tabular}

Keterangan : Nilai rata-rata yang ditandai dengan huruf yang sama menunjukan tidak berbeda nyata pada taraf 5\% menurut uji Duncan. Notasi huruf kecil dibaca horizontal sedangkan notasi huruf kapital dibaca vertikal.

Berdasarkan data pada Tabel 5, menunjukkan bahwa dengan semakin bertambahnya konsentrasi pemanis buatan, dan konsentrasi karagenan, maka viskositas minuman jeli ikan lele semakin meningkat. Hal ini, disebabkan karena karagenan akan mengikat air dalam jumlah besar, karena semakin banyak air yang terikat, dan terperangkap sehingga larutan bersifat lebih kental.

Viskositas adalah derajat kekentalan suatu produk pangan. Viskositas suatu hidrokoloid dipengaruhi oleh beberapa faktor, yaitu konsentrasi karagenan, temperature, jenis karagenan, berat molekul dan adanya molekul-molekul lain. Jika konsentrasi karagenan meningkat maka viskositasnya akan meningkat secara logaritmik. Viskositas larutan karagenan terutama disebabkan oleh sifat karagenan sebagai polielektrolit. Gaya tolakan (repulsion) antar muatan-muatan negatif sepanjang rantai polimer yaitu gugus sulfat, mengakibatkan rantai molekul menegang. Karena sifat hidrofiliknya, polimer tersebut dikelilingi oleh molekul-molekul air yang termobilisasi, sehingga menyebabkan larutan karagenan bersifat kental. Adanya garam-garam yang terlarut dalam karagenan akan menurunkan muatan bersih sepanjang rantai polimer. Penurunan muatan ini menyebabkan penurunan gaya tolakan (repulsion) antar gugus-gugus sulfat, sehingga sifat hidrofilik polimer semakin lemah dan menyebabkan viskositas larutan menurun. Viskositas larutan karagenan akan menurun seiring dengan peningkatan suhu sehingga terjadi depolimerisasi yang kemudian dilanjutkan dengan degradasi karagenan (Towle, 1973).

\section{Total Padatan Terlarut}

Berdasarkan data hasil perhitungan anava, konsentrasi karagenan, konsentrasi pemanis buatan, dan interaksi konsentrasi pemanis buatan, dan konsentrasi karagenan berpengaruh nyata terhadap respon uji total padatan terlarut yang diuji dengan menggunakan alat refraktometer. Pengaruh pemanis buatan (A) dapat dilihat pada Tabel 6 di bawah ini

Tabel 6. Pengaruh Konsentrasi Pemanis Buatan Terhadap Rerata Nilai Total Padatan Terlarut Minuman Jeli Ikan Lele

\begin{tabular}{|c|c|}
\hline $\begin{array}{c}\text { Konsentrasi Pemanis } \\
\text { Buatan }\end{array}$ & $\begin{array}{c}\text { Rerata Nilai Total } \\
\text { Padatan Terlarut }\left({ }^{\circ} \text { Brix }\right)\end{array}$ \\
\hline a1 $(0.02 \%: 0.06 \%)$ & 13,41 \\
\hline a2 $(0.014 \%: 0.042 \%)$ & 16,20 \\
\hline a3 $(0.01 \%: 0.03 \%)$ & 29,05 \\
\hline
\end{tabular}

Keterangan : Setiap huruf yang berbeda menunjukkan adanya perbedaan yang nyata pada taraf 5\% Uji Duncan.

Tabel 6, menunjukkan bahwa dengan semakin bertambahnya konsentrasi pemanis buatan, maka total padatan terlarut minuman jeli ikan lele semakin meningkat. Hal ini, disebabkan karena total padatan terlatut ini berhubungunan dengan gula yang nantinya dapat diketahui berapa persen tingkat kemanisan gula, semakin tinggi \% brix semakin tinggi kemanisan gulanya (Perwira,2010).

Tabel 7. Pengaruh Konsentrasi Karagenan Terhadap Total Padatan Terlarut Minuman Jeli Ikan Lele

\begin{tabular}{|c|c|}
\hline Konsentrasi Karagenan & $\begin{array}{c}\text { Rerata Nilai Total Padatan } \\
\text { Terlarut }\left({ }^{\circ} \text { Brix }\right)\end{array}$ \\
\hline b1 $(0.1 \%)$ & 15,36 \\
\hline b2 $(0.2 \%)$ & 16,25 \\
\hline b3 $(0.3 \%)$ & 17,37 \\
\hline
\end{tabular}

Keterangan : Setiap huruf yang berbeda menunjukkan adanya perbedaan yang nyata pada taraf $5 \%$ Uji Duncan.

Berdasarkan data pada Tabel 7, menunjukkan bahwa total padatan terlarut minuman jeli ikan lele semakin meningkat dengan semakin bertambahnya konsentrasi karagenan. Hal ini disebabkan karena total padatan terlarut "jelly" berasal dari bahan pengental, $\mathrm{Na}$ Benzoat, gula yang ditambahkan. Sehingga banyak karagenan dan pemanis buatan yang ditambahkan maka akan mempengaruhi Total Padatan Terlarut (TSS) pada minuman jeli ikan lele. Oleh karena itu semakin tinggi atau semakin banyak konsentrasi karagenan dan konsentrasi pemanis buatan yang digunakan, maka semakin tinggi kadar total padatan terlarutnya (Alistair, 1995).

Pengaruh interaksi konsentrasi pemanis buatan (A) dan konsentrasi pemanis buatan (B) dapat dilihat pada Tabel 8 di bawah ini. 
Tabel 8. Dwi Arah Terhadap Total Padatan Terlarut Minuman Jeli Ikan Lele

\begin{tabular}{|c|c|c|c|}
\hline \multirow{2}{*}{$\begin{array}{c}\text { Pemanis Buatan } \\
\text { (A) }\end{array}$} & \multicolumn{3}{|c|}{ Karagenan (B) } \\
\cline { 2 - 4 } & b1 & b2 & b3 \\
$(0.1 \%)$ & $(0.2 \%)$ & $(0.3 \%)$ \\
\hline \multirow{3}{*}{ a1 $(0.02 \%: 0.06 \%)$} & A & A & A \\
& 12,52 & 13,19 & 14,53 \\
& a & b & c \\
\hline \multirow{2}{*}{ a2 $(0.014 \%:$} & B & B & B \\
$0.042 \%)$ & 15,03 & 16,53 & 17,03 \\
& a & b & c \\
\hline & C & C & C \\
a3 $(0.01 \%: 0.03 \%)$ & 18,53 & 19,03 & 20,54 \\
& a & b & C \\
\hline
\end{tabular}

Keterangan : Nilai rata-rata yang ditandai dengan huruf yang sama menunjukan tidak berbeda nyata pada taraf 5\% menurut uji Duncan. Notasi huruf kecil dibaca horizontal sedangkan notasi huruf kapital dibaca vertikal.

Data menunjukkan bahwa dengan semakin bertambahnya konsentrasi pemanis buatan, dan konsentrasi karagenan, maka total padatan terlarut minuman jeli ikan lele semakin meningkat. Hal ini, disebabkan karena TSS (Total suspended Solid) merupakan kadar total padatan terlarut dalam suatu bahan makanan. Bahan makanan yang dicuci terlalu lama akan menyebabkan hilangnya kandungan gizi dalam jumlah banyak, selain itu pemanasan yang terlalu lama juga dapat menyebabkan hilangnya kandungan gizi dalam bahan makanan tersebut (Buckle dkk, 1987).

\section{pH}

Berdasarkan data hasil perhitungan anava, konsentrasi karagenan dan interaksi konsentrasi pemanis buatan dengan konsentrasi karagenan berpengaruh nyata terhadap respon uji $\mathrm{pH}$ yang diuji dengan menggunakan alat $\mathrm{pH}$ meter.

Tabel 9. Pengaruh Konsentrasi Pemanis Buatan Terhadap pH Minuman Jeli Ikan Lele

\begin{tabular}{|c|c|}
\hline Konsentrasi Pemanis Buatan (A) & Rerata Nilai $\mathrm{pH}$ \\
\hline $\mathrm{a} 1(0.02 \%: 0.06 \%)$ & 5,32 \\
\hline $\mathrm{a} 2(0.014 \%: 0.042 \%)$ & 5,46 \\
\hline $\mathrm{a} 3(0.01 \%: 0.03 \%)$ & 5,53 \\
\hline
\end{tabular}

Keterangan : Setiap huruf yang berbeda menunjukkan adanya perbedaan yang nyata pada taraf $5 \%$ Uji Duncan.

Hasil analisis konsentrasi pemanis buatan terhadap $\mathrm{pH}$ minuman jeli ikan menunjukkan bahwa $\mathrm{pH}$ meningkat dengan semakin meningkatnya konsentrasi pemanis. Hal ini, disebabkan karena karagenan dalam larutan memiliki stabilitas maksimum pada $\mathrm{pH}$ 9, dan akan terhidrolisis pada $\mathrm{pH}$ dibawah 3,5.
Kondisi proses produksi karagenan dapat dipertahankan pada $\mathrm{pH} 6$ atau lebih. Hidrolisis asam akan terjadi jika karagenan berada dalam bentuk larutan, hidrolisis akan meningkat sesuai dengan peningkatan suhu. Larutan karagenan akan menurun viskositasnya jika pHnya diturunkan dibawah 4,3 (Imeson, 2000).

Penurunan $\mathrm{pH}$ menyebabkan terjadinya hidrolisis dari ikatan glikosidik yang mengakibatkan kehilangan viskositas. Hidrolisis dipengaruhi oleh $\mathrm{pH}$, temperature, dan waktu (Imeson, 2000).

Pengaruh interaksi konsentrasi pemanis buatan (A) dan konsentrasi pemanis buatan (B) dapat dilihat pada Tabel 9 di bawah ini :

Tabel 9. Dwi Arah Terhadap pH Minuman Jeli Ikan Lele

\begin{tabular}{|l|l|l|l|}
\hline \multirow{2}{*}{$\begin{array}{l}\text { Pemanis Buatan } \\
\text { (A) }\end{array}$} & \multicolumn{3}{|l|}{ Karagenan (B) } \\
\cline { 2 - 4 } & $\begin{array}{l}\text { b1 } \\
(0.1 \%)\end{array}$ & $\begin{array}{l}\text { b2 } \\
(0.2 \%)\end{array}$ & $\begin{array}{l}\text { b3 } \\
(0.3 \%)\end{array}$ \\
\hline \multirow{2}{*}{ a1 $(0.02 \%: 0.06 \%)$} & C & A & A \\
& 5,70 & 5,20 & 5,30 \\
c & a & b \\
\hline \multirow{2}{*}{$\begin{array}{l}\text { a2 }(0.014 \% \\
0.042 \%)\end{array}$} & A & A & C \\
& 5,33 & 5,37 & 5,59 \\
a3 $(0.01 \%: 0.03 \%)$ & a & b & b \\
& 5,58 & C & B \\
& b & 5,40 & 5,50 \\
\hline
\end{tabular}

Keterangan : Nilai rata-rata yang ditandai dengan huruf yang sama menunjukan tidak berbeda nyata pada taraf 5\% menurut uji Duncan. Notasi huruf kecil dibaca horizontal sedangkan notasi huruf kapital dibaca vertikal.

Hasil perhitungan anava menunjukan bahwa konsentrasi karagenan, konsentrasi pemanis buatan, dan interaksi konsentrasi pemanis buatan dan konsentrasi karagenan berpengaruh nyata terhadap respon uji $\mathrm{pH}$.

Penambahan pemanis buatan dapat berpengaruh terhadap kadar minuman jeli ikan lele, dimana penambahan pemanis buatan akan mempengahuri $\mathrm{pH}$ minuman jeli ikan lele dimana semakin tinggi kadar pemanis buatan yang ditambahkan maka pH akan meningkat, hal itu terjadi karena karagenan stabil pada pH 6 (Glicksman, 1983).

Karagenan dalam larutan memiliki stabilitas maksimum pada $\mathrm{pH} 9$ dan akan terhidrolisis pada $\mathrm{pH}$ dibawah 3,5. Kondisi proses produksi karagenan dapat dipertahankan pada pH 6 atau lebih. Hidrolisis asam akan terjadi jika karagenan berada dalam bentuk larutan, hidrolisis akan meningkat sesuai dengan peningkatan suhu. Larutan karagenan akan menurun viskositasnya jika pHnya diturunkan dibawah 4,3. Kappa dan iota karagenan dapat digunakan sebagai pembentuk gel pada $\mathrm{pH}$ rendah, tetapi tidak mudah 
terhidrolisis sehingga tidak dapat digunakan dalam pengolahan pangan. Penurunan $\mathrm{pH}$ menyebabkan terjadinya hidrolisis dari ikatan glikosidik yang mengakibatkan kehilangan viskositas. Hidrolisis dipengaruhi oleh $\mathrm{pH}$, temperatur dan waktu (Anggraini, 2008).

\section{Respon Organoleptik}

\section{Warna}

Berdasarkan data hasil perhitungan anava,menunjukan bahwa faktor konsentrasi pemanis buatan (A), konsentrasi karagenan (B), dan interaksi konsentrasi pemanis buatan, dan konsentrasi karagenan (AB) tidak berpengaruh nyata terhadap warna minuman jeli ikan lele.

Pada faktor penambahan pemanis buatan dengan kosentrasi yang berbeda, dan penambahan karagenan dengan konsentrasi yang berbeda berdasarkan pengujian hedonik menghasilkan pengaruh yang tidak nyata, sebenarnya terdapat perubahan namun perubahan yang sangat kecil, hal ini disebabkan karena rentang antara konsentrasi baik itu pemanis buatan ataupun karagenan sangat kecil, sehingga perubahan warna yang terjadi tidak nyata.

Warna minuman jeli ikan lele adalah putih kecoklatan. Warna ini dipengaruhi oleh bahan-bahan yang digunakan, yaitu sari daging ikan lele, pemanis buatan, dan karagenan. Menurut Muchtadi dan Sugiyono (2013), warna bahan pangan dapat disebabkan oleh beberapa sumber, dan salah satu yang terpenting adalah pigmen yang ada dalam tanaman atau hewan.

Warna merupakan suatu sifat bahan yang dianggap berasal dari penyebaran spektrum sinar, begituh juga sifat kelip dari bahan dipengaruhi oleh sinar terutama sinar pantul. Warna bukan merupakan suatu zat atau benda, melainkan suatu sensasi seseorang oleh karena adanya rangsangan dari seberkas energi radiasi yang jatuh ke indera atau retina mata. Timbulnya warna dibatasi oleh faktor terdapatnya sumber sinar, pengaruh tersebut terlihat apabila suatu bahan dilihat ditempat yang gelap akan memberikan perbedaan yang menyolok (Kartika, dkk., 1988).

\section{Aroma}

Berdasarkan hasil perhitungan anava, menunjukan bahwa faktor konsentrasi pemanis buatan (A), konsentrasi karagenan (B), dan interaksi konsentrasi pemanis buatan, dan konsentrasi karagenan (AB) tidak berpengaruh nyata terhadap aroma minuman jeli ikan lele.

Aroma merupakan rangsangan yang ditimbulkan oleh bahan yang dicium, terutama yang dirasakan oleh indera pembau (Ashadi, 2014). Aroma merupakan sifat bahan (makanan), dan juga mekanisme reseptor orang yang mengkonsumsinya. Aroma mencakup susunan senyawa dalam makanan yang mengandung rasa atau bau, dan juga interaksi senyawa-senyawa ini dengan reseptor alat indera, dan bau. Efek gabungan menciptakan kesan yang sangat berbeda dengan aroma komponen satu-persatu (DeMan, 1997). Zat organic sangat sensitive terhadap udara, panas dan terhadap interaksinya satu sama lain. Citarasa dan aroma dari kopi, susu, daging dan sebagian besar bahan pangan lainnya biasanya mengalami perubahan yang secara konstan berkurang selama penanganan, pengolahan dan penyimpanan (Muchtadi, dan Sugiyono, 2013). Oleh karena itu semakin tinggi konsentrasi karagenan yang ditambahkan, maka aroma bau amis sari daging ikan lele yang dihasilkan setelah proses pengolahan semakin tertutupi. Selain itu aroma amis ikan lele yang berasal dari senyawa amina tersier (trimetilamina) sudah hilang bereaksi dengan asam sitrat dari air perasan jeruk lemon pada treatment perendaman daging ikan lele sebelum digunakan untuk membuat sari daging ikan lele.

\section{Rasa}

Berdasarkan data hasil perhitungan anva, menunjukan bahwa faktor konsentrasi pemanis buatan (A), konsentrasi karagenan (B), dan interaksi konsentrasi pemanis buatan, dan konsentrasi karagenan (AB) berpengaruh nyata terhadap rasa minuman jeli ikan lele.

Tabel 10. Pengaruh Pemanis Buatan Terhadap Rasa Minuman Jeli Ikan Lele

\begin{tabular}{|c|c|}
\hline $\begin{array}{c}\text { Konsentrasi Pemanis } \\
\text { Buatan }(\mathrm{A})\end{array}$ & Rerata Nilai Rasa \\
\hline $\mathrm{a} 1(0.02 \%: 0.06 \%)$ & $3,01^{\mathrm{a}}$ \\
\hline $\mathrm{a} 2(0.014 \%: 0.042 \%)$ & $3,08^{\mathrm{a}}$ \\
\hline $\mathrm{a} 3(0.01 \%: 0.03 \%)$ & $3,34^{\mathrm{b}}$ \\
\hline
\end{tabular}

Keterangan : Setiap huruf yang berbeda menunjukkan adanya perbedaan yang nyata pada taraf $5 \% \mathrm{Uji}$ Duncan.

Tabel 11. Pengaruh Konsentrasi Karagenan Terhadap Rasa Minuman Jeli Ikan ele

\begin{tabular}{|l|l|}
\hline Konsentrasi Karagenan (B) & Rata-Rata \\
\hline b1 $(0.1 \%)$ & $3,00^{\mathrm{a}}$ \\
\hline b2 $(0.2 \%)$ & $3,19^{\mathrm{ab}}$ \\
\hline b3 $(0.3 \%)$ & $3,24^{\mathrm{b}}$ \\
\hline
\end{tabular}

Keterangan : Setiap huruf yang berbeda menunjukkan adanya perbedaan yang nyata pada taraf $5 \%$ Uji Duncan.

Pengaruh interaksi konsentrasi pemanis buatan (A) dan konsentrasi pemanis buatan (B) dapat dilihat pada Tabel 12 di bawah ini. 
Tabel 12. Dwi Arah Terhadap Rasa Minuman Jeli Ikan Lele

\begin{tabular}{|c|c|c|c|}
\hline \multirow{2}{*}{$\begin{array}{c}\text { Pemanis Buatan } \\
\text { (A) }\end{array}$} & \multicolumn{3}{|c|}{ Karagenan (B) } \\
\cline { 2 - 4 } & $\mathrm{b} 1$ & $\mathrm{~b} 2$ & $\mathrm{~b} 3$ \\
$(0.1 \%)$ & $(0.2 \%)$ & $(0.3 \%)$ \\
\hline \multirow{3}{*}{ a1 $(0.02 \%: 0.06 \%)$} & $\mathrm{A}$ & $\mathrm{B}$ & $\mathrm{A}$ \\
& 3,043 & 3,313 & 2,877 \\
& $\mathrm{a}$ & $\mathrm{b}$ & $\mathrm{a}$ \\
\hline \multirow{2}{*}{$\mathrm{a} 2(0.014 \%:$} & $\mathrm{A}$ & $\mathrm{A}$ & $\mathrm{B}$ \\
$0.042 \%)$ & 2,957 & 2,903 & 3,167 \\
& $\mathrm{a}$ & $\mathrm{a}$ & $\mathrm{b}$ \\
\hline & $\mathrm{A}$ & $\mathrm{C}$ & $\mathrm{C}$ \\
$\mathrm{a} 3(0.01 \%: 0.03 \%)$ & 2,997 & 3,510 & 3,523 \\
& $\mathrm{a}$ & $\mathrm{b}$ & $\mathrm{b}$ \\
\hline
\end{tabular}

Keterangan : Nilai rata-rata yang ditandai dengan huruf yang sama menunjukan tidak berbeda nyata pada taraf 5\% menurut uji Duncan. Notasi huruf kecil dibaca horizontal sedangkan notasi huruf kapital dibaca vertikal.

Tabel 12 menunjukkan bahwa dengan semakin bertambahnya karagenan dan pemanis buatan, maka tingkat kesukaan panelis terhadap rasa minuman jeli ikan lele semakin meningkat. Penambahan karagenan dan pemanis buatan diduga dapat mempengaruhi rasa dari minuman jeli ikan lele. Hal ini terjadi karena perbedaan konsentrasi karagenan yang digunakan hanya sedikit, yaitu $0.1 \%$ sehingga panelis sulit membedakan minuman jeli ikan lele tersebut.

Rasa minuman jeli ikan lele berasal dari sari daging ikan lele dan pemanis buatan. Pemanis buatan digunakan sebagai bahan pemanis. Tujuan penambahan bahan pemanis adalah untuk memperbaiki flavor (rasa dan bau) bahan makanan sehingga asa manis yang timbul dapat meningkatakan kelezatan (Yuianti, 2008).

\section{Tekstur}

Berdasarkan data hasil perhitungan anva, menunjukan bahwa faktor konsentrasi pemanis buatan (A), konsentrasi karagenan (B), dan interaksi konsentrasi pemanis buatan, dan konsentrasi karagenan (AB) berpengaruh nyata terhadap tekstur minuman jeli ikan lele.

Tabel 13. Pengaruh Pemanis Buatan Terhadap Tekstur Minuman Jeli Ikan Lele

\begin{tabular}{|c|c|}
\hline $\begin{array}{c}\text { Konsentrasi Pemanis } \\
\text { Buatan }(\mathrm{A})\end{array}$ & Rerata Nilai Tekstur \\
\hline $\mathrm{a} 1(0.02 \%: 0.06 \%)$ & $3,01^{\mathrm{a}}$ \\
\hline $\mathrm{a} 2(0.014 \%: 0.042 \%)$ & $3,31^{\mathrm{b}}$ \\
\hline $\mathrm{a} 3(0.01 \%: 0.03 \%)$ & $3,35^{\mathrm{b}}$ \\
\hline
\end{tabular}

Keterangan : Setiap huruf yang berbeda menunjukkan adanya perbedaan yang nyata pada taraf $5 \%$ Uji Duncan.
Tabel 14. Pengaruh Konsentrasi Karagenan (B) Terhadap RasaTekstur Minuman Jeli Ikan Lele

\begin{tabular}{|c|c|}
\hline $\begin{array}{c}\text { Konsentrasi Karagenan } \\
(\mathrm{B})\end{array}$ & Rerata Nilai Tekstur \\
\hline b1 $(0.1 \%)$ & $3,03^{\mathrm{a}}$ \\
\hline b2 $(0.2 \%)$ & $3,25^{\mathrm{b}}$ \\
\hline b3 $(0.3 \%)$ & $3,39^{\mathrm{b}}$ \\
\hline
\end{tabular}

Keterangan : Setiap huruf yang berbeda menunjukkan adanya perbedaan yang nyata pada taraf $5 \%$ Uji Duncan.

Tabel 15. Dwi Arah Terhadap Tekstur Minuman Jeli Ikan Lele

\begin{tabular}{|c|c|c|c|}
\hline \multirow{2}{*}{$\begin{array}{c}\text { Pemanis Buatan } \\
\text { (A) }\end{array}$} & \multicolumn{3}{|c|}{ Karagenan (B) } \\
\cline { 2 - 4 } & $\mathrm{b} 1$ & $\mathrm{~b} 2$ & $\mathrm{~b} 3$ \\
$(0.1 \%)$ & $(0.2 \%)$ & $(0.3 \%)$ \\
\hline \multirow{3}{*}{ a1 $(0.02 \%: 0.06 \%)$} & $\mathrm{A}$ & $\mathrm{A}$ & $\mathrm{B}$ \\
& 2,52 & 3,13 & 3,38 \\
$\mathrm{~b}$ & $\mathrm{a}$ & $\mathrm{c}$ \\
\hline \multirow{2}{*}{ 22 $(0.014 \%:$} & $\mathrm{A}$ & $\mathrm{B}$ & $\mathrm{A}$ \\
$0.042 \%)$ & 3,39 & 3,34 & 3,32 \\
& $\mathrm{Ab}$ & $\mathrm{b}$ & $\mathrm{a}$ \\
\hline & $\mathrm{B}$ & $\mathrm{B}$ & $\mathrm{B}$ \\
a3 $(0.01 \%: 0.03 \%)$ & 3,19 & 3,27 & 3,47 \\
& $\mathrm{~B}$ & $\mathrm{a}$ & $\mathrm{ab}$ \\
\hline
\end{tabular}

Keterangan : Nilai rata-rata yang ditandai dengan huruf yang sama menunjukan tidak berbeda nyata pada taraf $5 \%$ menurut uji Duncan. Notasi huruf kecil dibaca horizontal sedangkan notasi huruf kapital dibaca vertikal.

Tabel 15 menunjukkan semakin meningkatnya konsentrasi karagenan semakin tinggi nilai kesukaan dalam hal tekstur, hal ini karena dengan sifat karagenan yang merupakan hidrokoloid yang dapat membentuk gel, semakin rendah konsentrasi karagenan, maka gel yang dihasilkan semakin rapuh sehingga gel yang dihasilkan tidak terlalu disukai, dan kadar airnya terlalu tiggi.

Tekstur dalam minuman jeli dipengaruhi oleh viskositas atau kekentalan minuman jeli. Viskositas yaitu derajat kekentalan suatu produk pangan.Viskositas dipengaruhi oleh besarnya konsentrasi bahan pengental yang ditambahkan dalam hal ini adalah karagenan. Kekentalan dinyatakan sebagai daya tahan yang diberikan oleh suatu cairan terhadap gerakan-gerakan yang dikenakan pada cairan tersebut (Fardiaz, 1989).

\section{Penentuan Sampel Terpilih}

Produk terpilih dilihat dari setiap atribut yang ada yaitu respon kimia, respon fisik, dan respon organoleptik meliputi warna, aroma, rasa, dan tekstur. Berdasarkan seluruh respon organoleptik yang dihasilkan dapat disimpulkan bahwa produk terpilih adalah perlakuan variasi pemanis buatan (Sakarin : 
Siklamat $\quad(0.01 \%: 0.03 \%)$ dengan konsentrasi karagenan $0.3 \%$ (a3b3). Hasil uji kadar protein dari produk terpilih adalah sebesar $3.80 \%$. Kadar protein pada minuman jeli ikan lele sampel terpilih cenderung turun daripada kadar protein sari daging ikan lele yang digunakan. Sari daging ikan lele yang digunakan memiliki kadar protein sebesar $7.91 \%$ sedangkan setelah dibuat menjadi minuman jeli ikan lele kadar protein turun menjadi $3.80 \%$. Hal ini disebabkan oleh proses pengolahan minuman jeli ikan lele tersebut diantaranya adalah pemanasan pada suhu $80^{\circ} \mathrm{C}$. Menurut Poedjiadi dan Supriyanti (2005), protein akan mengalami koagulasi apabila dipanaskan pada suhu $50^{\circ} \mathrm{C}$ atau lebih. Protein dapat dirusak oleh panas yang berelebihan, bahan kimia, pengadukan yang berelebihan terhadap solusi protein dan adanya penambahan asam dan basa. Pada proses pengolahan minuman jeli ikan lele, sari daging ikan lele dipanaskan dan diaduk pada suhu $80^{\circ} \mathrm{C}$ selama 5 menit. Hal ini yang menyebabkan turunnya kadar protein.

\section{Kesimpulan Dan Saran Kesimpulan}

Jenis pemanis buatan yang sesuai dengan minuman jeli ikan lele, yaitu Sakarin : Siklamat. Konsentrasi pemanis buatan berpengaruh nyata terhadap karakteristik minuman jeli ikan lele, yaitu terhadap respon viskositas, total padatan terlarut, rasa, dan tekstur. Tetapi tidak berpengaruh nyata terhadap respon kadar gula reduksi, $\mathrm{pH}$, warna, dan aroma. Konsentrasi karagenan berpengaruh nyata terhadap karakteristik minuman jeli ikan lele, yaitu terhadap respon viskositas, total padatan terlarut, $\mathrm{pH}$, rasa, dan tekstur. Tetapi tidak berpengaruh nyata terhadap respon kadar gula reduksi, warna, dan aroma. Interaksi konsentrasi pemanis buatan, dan konsentrasi karagenan berpengaruh nyata terhadap karakteristik minuman jeli ikan lele, yaitu terhadap respon viskositas, total padatan terlarut, $\mathrm{pH}$, rasa, dan tekstur. Tetapi tidak berpengaruh nyata terhadap respon kadar gula reduksi, warna, dan aroma. Sampel terpilih adalah formula a3b3, yaitu dengan penambahan pemanis buatan sebanyak $0.1 \%$ : $0,03 \%$, dan karagenan sebanyak $0,3 \%$ dengan $\mathrm{pH} 5,50$, kadar gula pereduksi $7,17 \%$, viskositas $866,67 \mathrm{mPas}$, total padatan terlarut $20,54{ }^{\circ}$ Brix, dan kadar protein $3.80 \%$.

\section{Saran}

Perlu dilakukan penelitian lebih lanjut mengenai daya tahan simpan, sehingga diperoleh batas waktu kadaluarsa pada produk minuman jeli ikan lele. Perlu dilakukan penelitian lebih lanjut untuk mengetahui kemasan yang tepat untuk minuman jeli ikan lele. Perlu dilakukan penelitian lebih lanjut menganai kualitas mikrobiologi dari minuman jeli ikan lele. Penggunaan karagenan sebagai bahan pembentuk gel dapat dikaji kembali dengan menggunakan bahan pembentuk gel jenis lainnya. Penggunaan sakarin, dan siklamat sebagai bahan pemanis dapat dikaji kembali dengan menggunakan bahan pemanis jenis lainnya.

\section{Daftar Pustaka}

1. Alistair, S.M. 1995. Food Polysacharides and their application. Marcel Dekker. Inc. New York.

2. Anggraini, D. S. 2008. Pengaruh Konsentrasi Karagenan Dan Tripotassium Citrate Terhadap Sifat Fisikokimia Dan Organoleptik Jelly Drink. Skripsi. Universitas Katolik Widya Mandal. Surabaya.

3. Ansar. 2013. Pemanis Buatan. http://wawasanilmukimia.com. Diakses :18 Febuari 2017.

4. Ashadi, A. Susilo, B. Yulianingsih, R. 2014. Studi Komposisi Sari Jagung Manis dan Karagenan Pada Kualitas Jeli Jagung Manis. Jurnal Biopress Komoditas Tropis Vol.2 No.2. Universitas Brawijaya. Malang.

5. AOAC. 1995. Official Methods Of Analysis of The Association Of Official Analytical Chemists. 16 th Edition. Vol 2. Benjamin Franklin Station. Washington D.C.

6. Arifin. 2002. Budidaya Lele. Effhar. Semarang.

7. Astawan, M. 2013. Pangan Fungsional Untuk Kesehatan yang Optimal. http://Kompas.com. Diakses :18 April 2016.

8. Astawan, M., 2008. Ikan Air Tawar Kaya Protein dan Vitamin. Artikel Departement of Food Science and Technology Bogor Agricultural University. http://web.ipb.ac.id. Diakses : 24 April 2016.

9. Badan Pengawasan Obat Dan Makanan. 2014. Kajjan Keamanan Bahan Tambahan Pangan Pemanis Buatan. Badan Pengawasan Obat Dan Makanan. Jakarta.

10. Buckle, K.A., Edwards, R.A., Fleet, G.H., Wootton M., 1985. Food Science. Penerjemah Hari Purnomo.UI-Press, Jakarta.

11. Cahyadi, W. 2008. Analisis Dan Aspek Kesehatan Bahan Tambahan Pangan. Bumi Aksara. Jakarta.

12. DeMan, J. 1997. Kimia Makanan. Edisi Kedua. ITB. Bandung.

13. Direktorat Jendral Perikanan Budidaya. 2014. Laporan Tahunan Direktorat Produksi Tahun 2014. http:// djpb.kkp.go.id. Diakses : 14 April 2016.

14. Fadillah, N. R, Sumartini, dan Widjaja, P. W. 2016. Pengaruh Konsentrasi Jelly Powder Terhadap Karakteristik Minuman Jeli Ikan Lele (Clarias sp.). Universitas Pasundan. Bandung.

15. Fardiaz, S. 1989. Hidrokoloid.Departemen Pendidikan dan Kebudayaan. Direktorat Jenderal Perguruan Tinggi. Pusat Antar Universitas Pangan dan Gizi.Institut Pertanian Bogor. Bogor. 
16. Febriyanti, S. dan Yunianta. 2015. Pengaruh Konsentrasi Karagenan dan Rasio Sari Jahe Emprit (Zingiber offinale var. Rubrum) Terhadap Sifat Fisik, Kimia, dan Organoleptik Jelly Drink Jahe. Jurnal Pangan dan Agroindustri Vol.3 No.2.Universitas Brawijaya. Malang.

17. Gaspersz, V. 1995. Teknik Analisis Dalam Penelitian Percobaan. Jilid 1 dan 2. Penerbit Parsito. Bandung.

18. Glicksman. 1983. Food Hydrocoloid. Vol. II. CRC Press.Inc. Florida.

19. Hapsari, A.P. 2011. Formulasi dan Karakteristikisasi Minuman Fungsional Fruity Jelly Yogurt Berbasis Kappa Karagenan Sebagai Sumber Serat Pangan. Institut Pertanian Bogor. Bogor.

20. Imeson, A. 2010. Food Stabilisers, Thickness and Gelling Agents. Markono Print Media Pte Ltd. Singapura.

21. Kartika, B., Hastuti, P., dan Supartono, W. 1998. Pedoman Uji Inderawi Bahan Pangan Berenergi, Edisi Pertama. UGM. Yogyakarta.

22. Limanto. 2011. Pengaruh Konsentrasi Karagenan dan Konsentrasi Natrium Sitrat Pada Jelly Drink Alang-Alang. http://respository.wima.ac.id. Diakses : 24 April 2016.

23. Mardiana, H.I. 2007. Pembuatan "Jelly Drink" Wortel (Daucus carrota L) Kajian Kombinasi Jenis dan Konsentrasi "Gelling Agent" (Agar dan Karagenan). Skripsi. Fakultas Teknologi Pertanian. Jurusan Teknologi Hasil Pertanian. Universitas Brawijaya. Malang.

24. Muchtadi, D. 2011. Karbohidrat Pangan dan Kesehatan Cetakan Kesatu. CV Alfabeta. Bandung.

25. Muchtadi, D., dan Sugiyono. 2015. Ilmu Pengetahuan Bahan Pangan Cetakan Kelima. CV Alfabeta. Bandung.

26. Perwira, T.I. 2010.Pengaruh Konsentrasi Karagenan dan Volume Sari Tomat Terhadap Sifat Fisik, Kimia dan Organoleptik Jelly Drink Tomat. http://eprints.umm.ac.id. Diakses : 18 April 2016.

27. POM. 2014. Mengenal Penggunaan Asesulfam-K Pada Pangan. http://ik.POM.go.id. Diakses :10 April 2017.

28. Pranajaya, D. 2007. Pendugaan Sisa Umur Simpan Minuman Jelly di Pasaran. Institut Pertanian Bogor. Bogor.

29. Rachman, A. 2005. Pengaruh Penambahan Karaginan dan Agar-agar pada Berbagai Konsentrasi Terhadap Sifat Fisik, Kimia, dan Organoleptik "Jelly Drink" Tomat (Lycopercium estelumtum Mill). Skripsi. Jurusan Teknologi Hasil Pertanian. Fakultas Teknologi Pertanian. Universitas Brawijaya. Malang.
30. Restiana, R.I., Wignyanto, Febrianto, A. 2013. Pembuatan Jelly Drink Filtrat Kulit Pisang Candi (Musa acuminata) (Kajian Penambahan Konsentrasi Karaginan dan Agar-agar). Universitas Brawijaya. Malang.

31. Sarwono B. 2001. Khasiat dan Manfaat Jeruk Nipis. Agromedia Pustaka : Jakarta

32. Soekarto, S.T. 1985. Dasar-Dasar Pengawasan dan Standarisasi Mutu Pangan. Jurusan Teknologi Pangan dan Gizi. Departemen Pendidikan dan Kebudayaan. Direktorat Jenderal Pendidikan Tinggi. Pusat Antar Universitas Pangan dan Gizi Institut Pertanian Bogor, Bogor.

33. Badan Standardisasi Nasional. 1994. SNI 01-35441994. Syarat Mutu Jelly.. Jakarta.

34. Sugiarso, A. dan Nisa, 2015. Pembuatan Minuman Jeli Murbei (Morus alba L.) dengan Pemanfaatan Tepung Porang (A. Muelleri blume) Sebagai Pensubtitusi Karagenan. Jurnal Pangan dan Agroindustri Vol.3 No.2.Universitas Brawijaya. Malang.

35. Suryaningrum T.D., Ikasari D., Murniyati. 2012. Aneka Produk Olahan Lele Edisi ke-1. Penebar Swadaya. Jakarta.

36. Suryanto, S.R. 2007. Budidaya Ikan Lele. Penebar Swadaya. Jakarta.

37. Usniati, S. 2004. Pemanis Alami dan Buatan untuk Kesehatan. Warta Penelitian dan Pengembangan Tanaman Industri 10 (1): 13 - 17.

38. Wicaksono, G.S. dan E. Zubaidah. 2015.Pengaruh Karagenan dan Lama Perebusan Daun Sirsak Terhadap Mutu dan Karakteristik Jelly Drink Daun Sirsak. Jurnal Pangan dan Agroindustri Vol.3 No.1. Universitas Brawijaya. Malang.

39. Winarno F.G. 1990. Teknologi Pengolahan Rumput Laut. Pustaka Sinar Harapan. Jakarta.

40. Willy Pranata Widjaja, A.S. Abdulamir, Nazamid B. Saari, Fatimah Bt Abu Bakar, Zamri B. Ishak. 2009. Fatty Acids Profie of Tropical Bagridae Catfish (Mystus nemurus) During Storage. American Journal of Food Technology 4(2) : 90-95.

41. Winarno, F.G. 2004. Kimia Pangan dan Gizi. Gramedia Pustaka Utama. Jakarta. 